\title{
Determination of Emissivity of Brass Alloy using Infrared Thermographic Technique
}

\section{Določitev emisivnosti medi z uporabo infrardeče termografije}

\author{
Zorana Lanc*, Milan Zeljković, Aleksandar Živković, Branko Štrbac, Miodrag Hadžistević \\ Faculty of Technical Sciences, University of Novi Sad, Serbia \\ *zoranalanc@uns.ac.rs
}

\begin{abstract}
This paper presents the experimental determination of the dependence of emissivity of brass on surface roughness and temperature. The investigation was conducted using the infrared thermographic technique on brass alloy C27200 workpieces with different degrees of surface roughness, during the continuous cooling process. The results obtained showed that the emissivity of the chosen brass alloy increases with greater surface roughness and decreases during the cooling process, its value ranging from 0.07 to 0.19 . It was concluded that surface roughness has a greater influence on the increase of the emissivity at higher temperatures, which can be seen in the three-dimensional infrared images. Multiple regression analysis confirmed a strong correlation between the examined parameters and the emissivity, and an original multiple regression model was determined.
\end{abstract}

Key words: emissivity, brass, infrared thermographic technique (ITT), three-dimensional infrared (3D IR) images, regression analysis.

\section{Povzetek}

V prispevku je prikazano eksperimentalno določanje emisivnosti medi glede na hrapavost in temperaturo površine. Izvedena je bila raziskava na obdelovancih iz medi C27200 z različnimi stopnjami hrapavosti površine med postopkom neprekinjenega hlajenja in $\mathrm{z}$ uporabo infrardeče termografije (ITT). Dobljeni rezultati so pokazali, da se emisivnost preizkušane medi poveča z večjo površinsko hrapavostjo in se med procesom hlajenja zmanjša, njena vrednost pa se giblje med 0,07 in 0,19 . Pri višjih temperaturah ima hrapavost večji vpliv na povečanje emisivnosti, kar je razvidno na tridimenzionalnih infrardečih slikah (3D IR). Večkratna regresijska analiza je potrdila močno korelacijo med preiskovanimi parametri in emisivnostjo. Določen je bil izvirni večkratni regresijski model.

Ključne besede: emisivnost, med, infrardeča termografija (ITT), tridimenzionalne infrardeče slike (3D IR), regresijska analiza. 


\section{Introduction}

Infrared thermographic technique (ITT) is one of the non-destructive testing techniques used for preventive and predictive maintenance, as well as for non-contact temperature measurement $[1,2]$. ITT works on the principle of transformation of spatial variations in the infrared (IR) radiation emitted from the surface of an observed object into a two-dimensional (2D) IR image, where the differences in temperature distribution are presented as a range of colours or tones [3]. The key material parameter for the practical use of ITT is emissivity. Emissivity is defined as the ratio of emissive power of the materials' surface (grey body) to that of an ideal black body under the same geometric and spectral conditions [4]. The emissivity of a metal can easily change due to physical and chemical conditions of the surface, such as the type of material, surface roughness, microstructure, temperature, wavelength, and so on [5]. Due to the low and varying emissivity of metals, numerous authors have investigated the effect of these mentioned parameters on metals' emissivity characteristics. Deheng et al. [6] studied the effect of surface oxidation on the spectral emissivity of brass over the temperature range from $527^{\circ} \mathrm{C}$ to $797^{\circ} \mathrm{C}$ at the wavelength of $1.5 \mu \mathrm{m}$. The temperature of the specimen surface is monitored by averaging the two R-type platinum-rhodium thermocouples. It was shown that the spectral emissivity of brass rapidly increases with increasing temperature [6]. Zhibin et al. [7] investigated the influence of the surface roughness on the emissivity of the $\mathrm{Au}$ films for high-temperature application. The samples were heated in air at $600^{\circ} \mathrm{C}$ for $200 \mathrm{~h}$ to simulate the application environment. The results showed that the substrate roughness had great influence on the emissivity characteristics of the Au films. The average IR emissivity of the samples with low roughness just increased a little after heat treatment, while it greatly increased for the sample with high roughness [7]. Wen and Mudawar [8] determined the emissivity of different aluminium alloys depending on temperature, surface roughness and oxidation, using multispectral radiation thermometry. At the same temperature, the emission spectra of different alloys were similar in shape, but oxi- dation led to significant differences in the magnitude. An increase in temperature and surface roughness mostly resulted in higher emissivity of the examined alloys $[9,10]$.

Previous studies showed that the emissivity of metals increases with increase in temperature and surface roughness during heating. This paper includes an investigation into the emissivity behaviour of the brass alloy C27200 during the continuous cooling process when using ITT. The reason for this is the similar heating and cooling rates of metals. For a more detailed analysis of the effect of surface roughness and temperature on the emissivity characteristics of brass alloy C27200, three-dimensional IR images (3D IR) were used. This study considered the possibility of use of multiple regression analysis for the theoretical determination of the emissivity, on the basis of experimentally obtained data. The aim of the study was to investigate whether ITT can be used for reliable temperature measurement of heated metal surfaces on the work equipment and, by implication, for the assessment of risk of burn injuries.

\section{Materials and methods}

The experimental determination of the emissivity was conducted on the brass alloy C27200. Due to the excellent mechanical properties, machinability and corrosion resistance of brass, it is widely used in pipes, valves and fittings in systems that transport water and other aqueous fluids [11]. Chemical characteristics of the chosen brass alloy are given in Table 1.

\begin{tabular}{ccccc} 
Table 1. Chemical characteristics of the chosen brass alloy \\
UNS No. ISO No. $\begin{array}{c}\text { Common } \\
\text { name }\end{array}$ & $\begin{array}{c}\text { Copper } \\
\%\end{array}$ & $\begin{array}{c}\text { Zinc } \\
\text { \% }\end{array}$ \\
\hline C27200 & CuZn37 & $\begin{array}{c}63 / 37 \\
\text { Common } \\
\text { brass }\end{array}$ & $62-65$ & $\sim 37$ \\
\hline
\end{tabular}

For the purpose of the experimental work, four workpieces were made with dimensions of $(150 \times 150 \times 10) \mathrm{mm}$. The first workpiece was ground, whereas the other three were milled under different regimes of face milling with the 


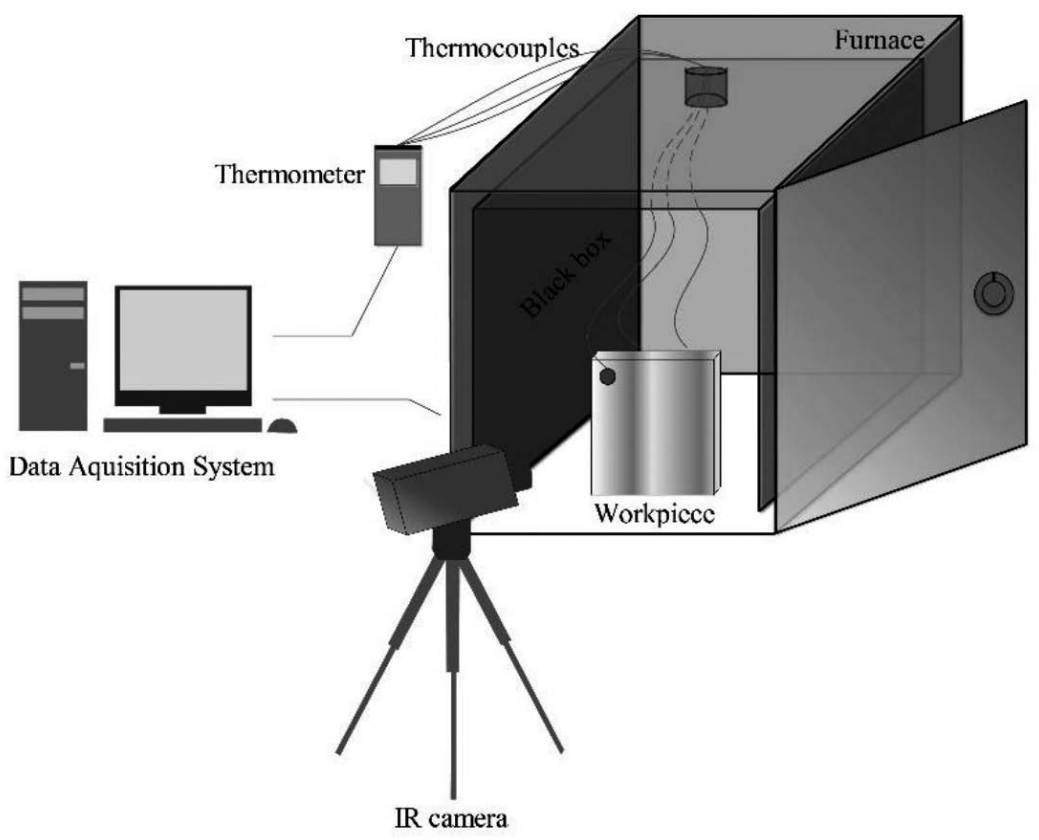

Figure 1. Experimental set-up.

Table 2. Surface roughness of the workpieces

\begin{tabular}{ccc}
$\begin{array}{c}\text { Type of } \\
\text { machining }\end{array}$ & $\begin{array}{c}\text { Roughness average, } \\
\overline{\boldsymbol{R a}}[\boldsymbol{\mu \mathrm { m } ]}\end{array}$ & Labels \\
\hline Grinding & 1.23 & $\mathrm{~B}_{1}$ \\
\hline \multirow{2}{*}{ Milling } & 3.24 & $\mathrm{~B}_{2}$ \\
\cline { 2 - 3 } & 3.38 & $\mathrm{~B}_{3}$ \\
\cline { 2 - 3 } & 3.92 & $\mathrm{~B}_{4}$ \\
\hline
\end{tabular}

aim of obtaining different surface qualities, i.e., roughness values. The roughness of the workpieces was measured with a contact method using a Mar Surf PS1 device. The mean roughness (roughness average, $R$ a) was measured at 30 points uniformly distributed on the surface of the workpiece. The average value of the measured roughness $(R a)$ was taken as the surface roughness of the workpiece (Table 2).

A common method for determining the emissivity using an IR camera is based on the simultaneous heating of a workpiece, measuring the temperature using an IR camera and measuring the reference temperature on the analysed surface. The reference temperature can be measured using a contact device for temperature measurement or by applying a special coating with known emissivity on the examined surface within the field of view of the IR camera. The emissivity is determined by adjusting the value from zero to one until the temperatures on the IR camera and the reference temperature are equal [12]. For the purpose of this paper, a heat treatment furnace was used for heating the workpieces. For achieving a uniform temperature distribution on the target area of the sample, every workpiece was placed upright in the centre of the furnace and tested separately. The radiation emitted from the heat furnace can affect the thermography test to a large extent. Thus, prior to the measurement, a 2-mm black tin box was placed into the furnace in order to eliminate the effect of the furnace walls on the measurement results. The IR camera used for thermal imaging was camera IR ThermoPro TP8S, with a spectral range of 8-14 $\mu \mathrm{m}$ and temperature accuracy of $\pm 1^{\circ} \mathrm{C}$. The reference temperature was measured using type-K thermocouples. Two thermocouples were placed on the back surface of the workpiece, whereas the third thermocouple was attached to the front surface of the workpiece using black rubber. The experimental set-up is presented in Figure 1.

After installing the thermocouples and setting the IR camera, a workpiece was heated up to $200^{\circ} \mathrm{C}$. On reaching this temperature, the work- 
piece was cooled down to the ambient temperature of $25^{\circ} \mathrm{C}$. At the same time, the camera took an IR image of the workpiece at every $10^{\circ} \mathrm{C}$ decrease in temperature. The described procedure was repeated for every workpiece. The obtained IR images were processed using the Guide Ir Analyser program, where the average emissivity of a workpiece was adjusted to a value ranging from zero to one until the temperature became equal to the reference temperature. During the IR-image processing step, the temperature used as the reference temperature was the average of the temperature values obtained with the thermocouples. The described method was used for determining the emissivity of all four workpieces at temperatures ranging from $50^{\circ} \mathrm{C}$ to $200^{\circ} \mathrm{C}$.

\section{Results and discussion}

The experimental data show that the average emissivity of brass alloy C27200 in the spectral range of 8-14 $\mu \mathrm{m}$ decreases during the cooling and mainly increases with an increase in the surface roughness (Figure 2). The emissivity ranges from 0.07 to 0.19 . At temperatures from $50^{\circ} \mathrm{C}$ to $120^{\circ} \mathrm{C}$, the emissivity values of the workpieces are constant, and their mutual differences are only the results of the surface roughness. At temperatures $>120^{\circ} \mathrm{C}$, the emissivity values increase, first with the $\mathrm{B}_{3}$ workpiece and finally with the $\mathrm{B}_{4}$ workpiece. The emissivity of the ground workpiece $B_{1}$ is the lowest and not prone to drastic changes as in the case of the other workpieces, which were milled.

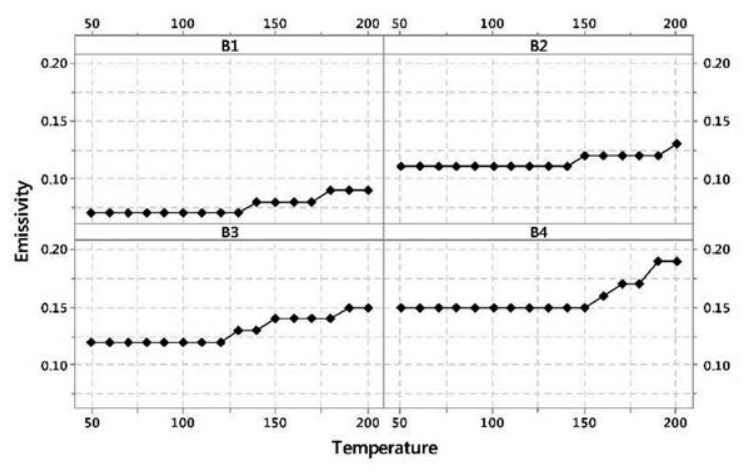

Figure 2. Emissivity of brass alloy C27200 at low and medium temperatures.

\section{Study of 3D IR images}

A more thorough investigation into the effects of the temperature and surface roughness on the emissivity was conducted using 3D IR images. 3D IR images are the three-dimensional representations of the surface of a workpiece, with more strictly defined boundaries between the areas with small temperature differences, which are almost invisible in a normal IR image. There are various commercial software programs for the construction of 3D IR images, but in this paper, we used the new method presented by Lanc et al. [13]. The method is based on exporting the temperature values per pixel of an IR image using the Guide Ir Analyser program into a Microsoft Excel table. In the table, the data are grouped in such a way that the $x$ and $y$-coordinates determine the position of a pixel in the IR image, whereas the $z$-coordinate determines its temperature. With a simple selection of all the data and the construction of a surface contour diagram in Microsoft Excel, 3D IR images are obtained. Figure 3 presents the 3D IR images of the ground workpiece $B_{1}$ and the workpiece with the greatest surface roughness, $\mathrm{B}_{4}$, at the temperature of $50^{\circ} \mathrm{C}$.

Their comparison shows that the temperature is more evenly distributed in the $\mathrm{B}_{4}$ workpiece than in the $B_{1}$ workpiece due to the more reflective surface of the $B_{1}$ workpiece. While measuring the arithmetic mean roughness using the Mar Surf PS1 device, it was noticed that the right side of the $\mathrm{B}_{4}$ workpiece had a greater roughness than the left side. These data correspond to the presented 3D IR images of the $\mathrm{B}_{4}$ workpieces. Although the average temperature of both workpieces was $200^{\circ} \mathrm{C}$, in the $\mathrm{B}_{4}$ workpiece, temperatures from $0^{\circ} \mathrm{C}$ to $50^{\circ} \mathrm{C}$ were more frequent than in the $\mathrm{B}_{1}$ workpiece, where the most frequent temperatures ranged from $50^{\circ} \mathrm{C}$ to $100^{\circ} \mathrm{C}$. The reflective surface contributed to the higher temperature of the $\mathrm{B}_{1}$ workpiece. The defects are clearly visible in Figure 4 and are represented with yellow areas, which correspond to the highest temperatures. In Figure 4, the temperature of black rubber is $>400^{\circ} \mathrm{C}$, although its real temperature is $200^{\circ} \mathrm{C}$. This error occurred because it is possible to adjust only one value of the emissivity in a 3D IR image. In this case, the values of the emissivity were adjusted for the $\mathrm{B}_{1}$ and $\mathrm{B}_{4}$ workpieces, 


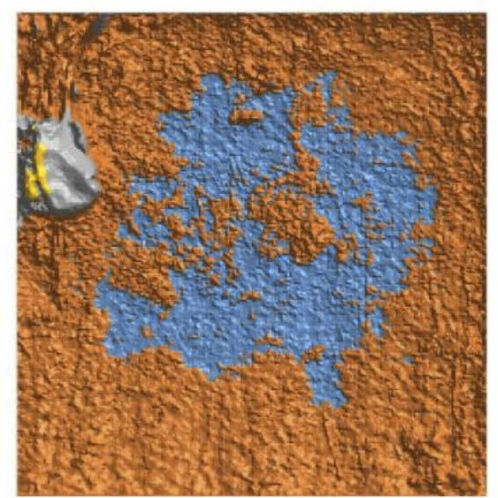

- $0-50 \quad$ =50-100 $=100-150 \quad=150-200$

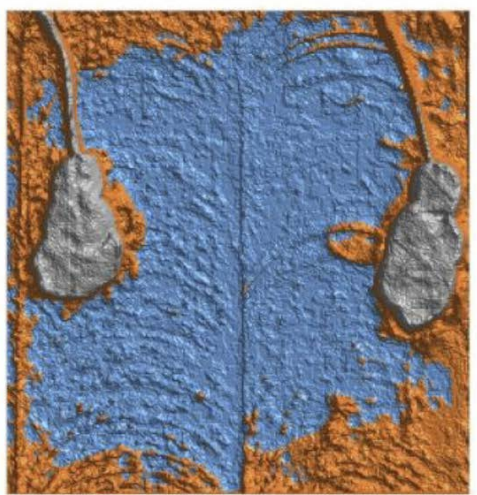

=0-50 $=50-100 \quad=100-150$

Figure 3. $3 D$ IR images of $B_{1}$ workpiece (left) and $B_{4}$ workpiece (right) at the temperature of $50^{\circ} \mathrm{C}$.
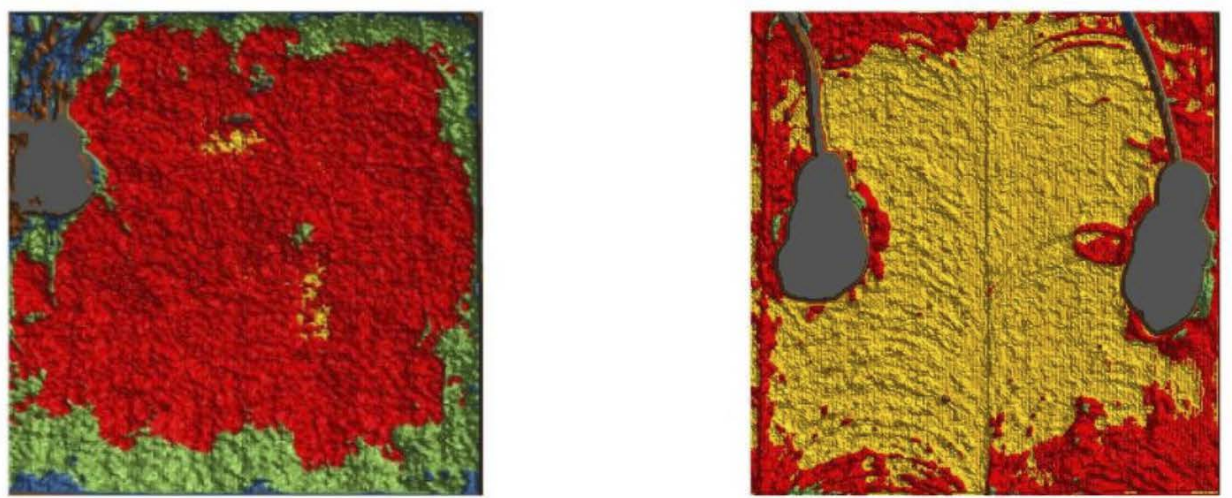

$\| 50-100=100-150=150-200=200-250=250-300=300-350=50-100=100-150=150-200=200-250=250-300=300-350$

Figure 4. 3D IR images of $B_{1}$ workpiece (left) and $B_{4}$ workpiece (right) at the temperature of $200^{\circ} \mathrm{C}$.

which is why the temperatures of black rubber drastically increased.

The effect of the reflected radiation on the bottom part of the workpiece is noticeable here as well, leading to the so-called 'false temperatures'. At higher temperatures, the differences in the surface roughness are more conspicuous than at lower temperatures. In the 3D IR images of the milled workpieces, the difference in the surface roughness is bigger at the temperature of $200^{\circ} \mathrm{C}$ than at the temperature of $50^{\circ} \mathrm{C}$. At higher temperatures, the milling direction and the boundaries between the tool passes are more conspicuous, which can be seen in the 3D IR images of the $B_{4}$ workpiece, whose surface was machined in two tool passes. This leads to a conclusion that the surface roughness causes a greater increase in the emissivity at higher temperatures.

\section{Multiple linear regression analysis}

Multiple regression analysis makes it possible to examine the effect of several independent variables on the dependent output variable. The result of this approach is a multiple regression model, which, in the form of a mathematical formula, connects the effect of two independent variables on the dependent variable [14]. In this concrete case, the dependent variable the emissivity $(\varepsilon)$ - is related to two independent variables - temperature (T) and surface roughness $\left(R_{\mathrm{a}}\right)$ - according to the following model (Equation 1):

$\varepsilon=\beta_{0}+\beta_{1} \cdot T+\beta_{2} \cdot R a+r$

where $\beta_{0^{\prime}} \beta_{1}, \beta_{2}, \beta_{0}$ represent the regression coefficients and $r$ is the component of random error. 


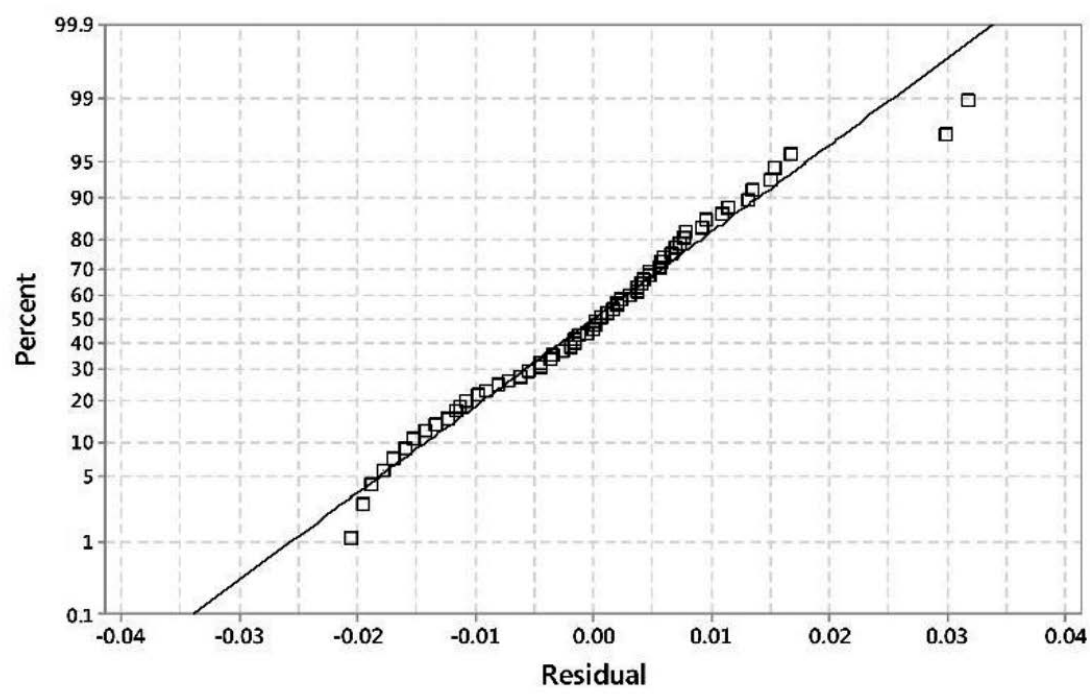

Figure 5. Scatter plot.

For assessment of the model for $n=64$ observations and the number of independent variables $k=2$, the matrix form of Equation 1 is given by the following matrix Equation 2:

$Y=\left[\begin{array}{c}e_{1} \\ e_{2} \\ \vdots \\ e_{64}\end{array}\right] ; X=\left[\begin{array}{ccc}1 & x_{11} & x_{12} \\ 1 & x_{21} & x_{22} \\ \vdots & \vdots & \vdots \\ 1 & x_{(64) 1} & x_{(64) 2}\end{array}\right]$

$\beta=\left[\begin{array}{c}\beta_{0} \\ \beta_{1} \\ \beta_{2}\end{array}\right] ; \beta=\left[\begin{array}{c}r_{0} \\ r_{1} \\ \vdots \\ r_{64}\end{array}\right]$

The matrix Equation 2 is solved according to results in the following multiple linear regression model (Equation 3):

$\mathcal{E}=0.000179 \cdot T+0.027565 \cdot R a-0.06101(3)$

The presented model can be used for the temperature range from $50^{\circ} \mathrm{C}$ to $200^{\circ} \mathrm{C}$ and surface roughness ranging from $1.23 \mu \mathrm{m}$ to $3.92 \mu \mathrm{m}$. In this case, the multiple coefficient of determination $R^{2}$ shows that $87.94 \%$ of the variation in the emissivity comes from variation in the temperature and surface roughness, whereas the remaining $13.06 \%$ is the consequence of the effect of other parameters, such as humidity, permeability of the atmosphere, temperature of the environment, and so on. The model can be used for prediction of the emissivity at tem- peratures and surface roughness values that are beyond the mentioned ranges, with a somewhat lower coefficient of determination $R^{2}$ pred of $87.55 \%$. Multiple regression was used to determine the strength of dependence between the emissivity and the observed parameters based on the correlation coefficient $r$. The correlation coefficient was 0.9 , which points to the fact that there is a strong (direct) linear dependence between temperature and surface roughness on the one hand and the emissivity on the other hand. The scatter plot (Figure 5) shows a small degree of data deviation around the established regression line, indicated by the value of the standard error $S$ of 0.01 .

\section{Conclusions}

The emissivity of brass alloy C27200 during the process of cooling from $200^{\circ} \mathrm{C}$ to $50^{\circ} \mathrm{C}$ was experimentally determined using the ITT.

The investigation showed that the emissivity of the chosen alloy ranges from 0.07 to 0.19 and that it decreases with decrease in temperature and increases with increase in surface roughness. At higher temperatures, the differences between the emissivity values of the workpieces are bigger. The analysis of 3D IR images showed that this phenomenon is a consequence of a more significant effect of surface roughness on the emissivity at higher temperatures. 
Additionally, the paper used a new method of creating 3D IR images using Microsoft Excel. This method is simple, and unlike commercial programs, it is more affordable. Although ITT is not recommendable for the precise determination of the emissivity of metals, in the post-processing stage of IR images, the authors managed to determine small variations in the emissivity, even when the differences between the IR images were $10^{\circ} \mathrm{C}$. Multiple regression analysis confirmed a strong correlation between the investigated parameters and the emissivity, and a multiple regression model was determined. The herein-presented model can only be applied with low and medium temperatures, since at higher temperatures, there is a somewhat greater deviation of the experimental data from the regression line. The reason for this is the uneven distribution of temperature on the surface of a workpiece due to the defects that occur during its machining.

\section{References}

[1] Krešák, J., Peterka, P., Kropuch, S., Novák, L. (2014): Measurement of tight in steel ropes by a mean of thermovision, Measurement, 50, pp. 93-98.

[2] Kosec, B., Karpe, B., Budak, I., Ličen, M., Đorđević, M., Nagode, A., Kosec, G. (2012): Efficiency and quality of inductive heating and quenching of planetary shafts, Metallurgy, 51, pp. 71-74.

[3] Glavaš, H., Jozsa, L., Barić, T. (2016): Infrared thermography in energy audit of electrical installations, Tehnički vjesnik, 23, pp. 1533-1539.

[4] HangJin, J., Jonathan, K., Kyle, B., Kumar, S. (2017): Spectral emissivity of oxidized and roughened metal surfaces. International Journal of Heat and Mass Transfer, 115, Part B, pp. 1065-1071.

[5] Švantner, M., Honnerová, P., Veselý, Z. (2016): The influence of furnace wall emissivity on steel charge heating. Infrared Physics \& Technology, 74, pp. 63-71.
[6] Deheng, S., Qionglan, L., Zunlue, Z., Jinfeng, S., Baokui, W. (2014): Experimental study of the relationships between the spectral emissivity of brass and the temperature in the oxidizing environment. Infrared Physics \& Technology, 64, pp. 119-124.

[7] Zhibin, H., Wancheng, Z., Xiufeng, T., Dongmei, Z., Fa, L. (2011): Effects of substrate roughness on infrared-emissivity characteristics of Au films deposited on Ni alloy. Thin Solid Films, 519, pp. 3100-3106.

[8] Wen, C.D., Mudawar, I. (2004): Emissivity characteristics of roughened aluminum alloy surfaces and assessment of multispectral radiation thermometry (MRT) emissivity models. International Journal of Heat and Mass Transfer, 47, pp. 3591-3605.

[9] Kosec, B., Kosec, G. (2003): Temperature field analysis on active working surface of the die-casting die. Metall, 57, pp. 134-136.

[10] Wen, C.D., Mudawar, I. (2006): Modeling the effects of surface roughness on the emissivity of aluminum alloys. International Journal of Heat and Mass Transfer, 49, pp. 4279-4289.

[11] Yang, C., Ding, Z., Tao, Q.C., Liang, L., Ding, Y.F., Zhang, W.W., Zhu, Q.L. (2018): High-strength and free-cutting silicon brass alloy C27200es designed via the zinc equivalent rule. Materials Science and Engineering, 723, pp. 296-305.

[12] Švantner, M., Vacíková, P., Honner, M. (2013): Non-contact charge temperature measurement on industrial continuous furnaces and steel charge emissivity analysis. Infrared Physics \& Technology, 61, pp. 20-26. doi: 10.1016/j.infrared.2013.07.005.

[13] Lanc, Z., Štrbac, B., Zeljković, M., Živković, A., Hadžistević, M. (2018): Emissivity of Aluminium Alloy using Infrared Thermographic Technique. Materials and Technology, 52, pp. 35-40.

[14] Motorcu, A.R., Isik, Y., Kus, A., Cakir, M.C. (2016): Analysis of the cutting temperature and surface roughness during the orthogonal machining of AISI 4140 alloy steel via the Taguchi method, Materials and technology, 50(3), 343-351. doi:10.17222/mit.2015.021. 